\title{
Pembelajaran Daring pada Pendidikan Tinggi: Tantangan Bagi Mahasiswa dan Dosen di Tengah Pandemi
}

\author{
Rizky Nastiti \\ Sekolah Tinggi Ilmu Ekonomi Indonesia Banjarmasin \\ Nurul Hayati \\ Sekolah Tinggi Ilmu Ekonomi Indonesia Banjarmasin \\ rizky@stiei-kayutangi-bjm.ac.id
}

\begin{abstract}
Abstrak
Penelitian ini bertujuan untuk menganalisa kesiapan dan tantangan yang dihadapi mahasiswa dan dosen saat perkuliahan daring di masa pandemi ini. Penelitian ini juga bertujuan menganalisa aspek positif yang dirasakan oleh mahasiswa dan dosen selama perkuliahan daring berlangsung. Pengambilan data dalam penelitian ini dilakukan dalam dua tahap. Tahap pertama adalah pengisian kuesioner oleh 142 responden mahasiswa dari berbagai perguruan tinggi di Kota Banjarmasin. Tahap kedua adalah pengisian kuesioner dan wawancara kepada enam orang dosen. Hasil dari penelitian ini menunjukkan bahwa baik mahasiswa maupun dosen memiliki kesiapan yang baik dalam menghadapi perkuliahan secara daring dikarenakan sebagaian besar telah memiliki dan mampu mempergunakan perangkat digital yang mendukung. Lebih lanjut lagi, dapat disimpulkan bahwa selama mengikuti perkuliahan secara daring, mahasiswa mengalami beberapa kendala antara lain merasa stress dan terbatasnya interaksi sosial. Selain itu, mahasiswa juga merasa kesulitan berkonsentrasi saat berkuliah secara daring dan merasa terbebani dengan tugas-tugas kuliah. Ditambah lagi dengan kendala jaringan internet yang tidak stabil dan penggunaan kuota internet yang boros. Meskipun mahasiswa mengalami berbagai kendala selama mengikuti perkuliahan secara daring, mereka juga merasakan dampak positifnya, salah satunya adalah memiliki lebih banyak waktu luang. Sedangkan kendala utama yang dihadapi oleh dosen adalah kurangnya interaksi dengan mahasiswa sehingga perkuliahan berlangsung kurang efektif.
\end{abstract}

Kata Kunci: pembelajaran daring, pendidikan tinggi, tantangan pembelajaran daring, pandemi

\section{Pendahuluan}

Pandemi COVID-19 merupakan sebuah ancaman kesehatan yang terjadi secara global dan berdampak terhadap berbagai aspek kehidupan. UNESCO (2020) melaporkan bahwa di akhir 2019, COVID-19 telah menyebar ke berbagai penjuru dunia dan menyebabkan kematian lebih dari 3.000 jiwa. Berbagai cara digalakkan dalam rangka memutus penyebaran virus ini. Salah satunya dengan melakukan penutupan terhadap sekolah dan perguruan tinggi.

Di Indonesia sendiri langkah pencegahan serupa juga dilakukan. Di tengah meningkatnya kekhawatiran akan penyebaran COVID-19, sejak pertengahan bulan Maret 2020 Kementerian Pendidikan dan Kebudayaan Republik Indonesia menerapkan kebijakan pembelajaran dari rumah. Hal ini dilaksanakan dalam rangka memutus mata rantai penyebaran COVID-19. Lebih lanjut lagi, Direktorat Jenderal Pendidikan Tinggi (Ditjen Dikti) juga mengimbau agar perguruan tinggi dengan otonomi yang dimilikinya dapat 
memberikan fleksibilitas dalam pelaksanaan pembelajaran jarak jauh di masa darurat COVID-19. Salah satunya dengan menerapkan sistem kuliah secara daring.

Sistem pembelajaran daring dijalankan sebagai sebuah solusi menangguhkan perkuliahan tatap muka tanpa menghentikan perkuliahan (Zhang dkk, 2020). Pembelajar daring sendiri dapat dimaknai sebagai pengalaman belajar dalam lingkungan sinkron atau asinkron menggunakan perangkat yang berbeda (misalnya, ponsel, laptop, dll.) dengan akses internet. Dalam lingkungan ini, siswa dapat berada di mana saja (mandiri) untuk belajar dan berinteraksi dengan instruktur dan siswa lainnya (Singh dan Thurman, 2019).

Pembelajaran daring memang telah menjadi solusi pembelajaran alternatif bagi dosen dan mahasiswa di tengah pandemi ini. Akan tetapi, persiapan yang baik terutama kesiapan dalam penggunaan perangkat pendukung sangat diperlukan dalam mengimplementasikan pembelajaran daring sehingga aktivitas perkuliahan dapat berjalan dengan efektif (Ana dkk, 2020; Ali, 2020). Pembelajaran daring memberikan fleksibilitas bagi pelaksanaan perkuliahan sehingga dapat digunakan secara luas. Selain itu, pelaksanaan pembelajaran daring dianggap dapat meningkatkan penggunaan teknologi dalam pembelajaran serta meningkatkan kemandirian belajar mahasiswa (Akkorful dan Abaidoo, 2020; Huang dkk, 2020; Firman, 2020).

Meskipun demikian, pembelajaran daring pada pendidikan tinggi tentu saja memiliki tantangan tersendiri. Salah satu kendala yang dialami mahasiswa saat menjalani perkuliahan secara daring adalah jaringan internet yang tidak stabil terutama bagi mereka yang tinggal di pelosok. Selain itu, tidak semua mahasiswa memiliki perangkat yang mendukung pembelajaran daring, seperti laptop, smartphone yang memadai serta jaringan Wi-Fi di rumah (Zhang dkk, 2020; Giatman dkk, 2020, Wijaya dkk, 2020).

Tantangan yang serupa juga dialami mahasiswa di Kota Banjarmasin, terutama bagi mahasiswa yang tinggal di daerah yang jaringan internetnya masih sangat terbatas. Sebagian mahasiswa juga memiliki kesulitan dalam menggunakan aplikasi pendukung perkuliahan daring. Tidak hanya mahasiswa, beberapa dosen dan tenaga pengajar pun juga mengalami kendala yang sama. Maka berdasarkan uraian tersebut, peneliti ingin menganalisa persepsi, kesiapan dan tantangan yang dihadapi tidak hanya mahasiswa tetapi juga dosen saat perkuliahan daring di masa pandemi ini. Peneliti juga ingin menganalisa aspek positif yang dirasakan oleh mahasiswa dan dosen selama perkuliahan daring berlangsung.

Oleh karena itu, rumusan masalah dari penelitian ini dapat dilihat dari pertanyaanpertanyaan berikut:

1. Bagaimana persepsi mahasiswa mengenai perkuliahan daring selama pandemi?

2. Bagaimana kesiapan mahasiswa saat pertama kali mengikuti perkuliahan daring?

3. Tantangan apa yang dihadapi mahasiwa selama mengikuti perkuliahan daring?

4. Aspek positif apa yang dirasakan mahasiswa selama mengikuti perkuliahan daring?

5. Bagaimana kesiapan dosen saat pertama kali mengajar perkuliahan daring?

6. Tantangan apa yang dihadapi dosen selama mengajar perkuliahan daring?

\section{Landasan Teori}

\section{Pembelajaran Daring}

Saat ini, sesuai dengan perkembangan situasi darurat COVID-19, beberapa negara telah mengadopsi berbagai pendekatan belajar mengajar yang fleksibel dalam sistem pendidikannya, dan pendidikan daring atau online menjadi salah satu pendekatan utama. 


\section{Rizky Nastiti, Nurul Hayati}

Pembelajaran daring, sebagai bagian dari pendidikan jarak jauh, selalu memperhatikan penyediaan akses ke pengalaman pendidikan yang setidaknya lebih fleksibel dalam waktu dan ruang daripada pendidikan berbasis kampus dengan memanfaatkan berbagai jenis teknologi (Huang dkk, 2020).

Hal ini berarti pembelajaran daring merupakan sebuah alternatif pembelajaran yang fleksibel di masa pandemi saat ini. Huang dkk (2020) menjelaskan konsep pedagogi fleksibel sebagai strategi pendidikan yang berpusat pada peserta didik, yang memberikan pilihan dari dimensi utama studi, seperti waktu dan lokasi pembelajaran, sumber daya untuk belajar mengajar, pendekatan instruksional, kegiatan pembelajaran, dukungan bagi guru dan peserta didik. Dengan cara ini, mengajar dan belajar bisa lebih fleksibel.

Secara umum, pembelajar daring didefinisikan sebagai pengalaman belajar dalam lingkungan sinkron atau asinkron menggunakan perangkat yang berbeda (misalnya, ponsel, laptop, video, chat atau interaksi dunia visual.) dengan akses internet. Dalam lingkungan ini, siswa dapat berada di mana saja (mandiri) untuk belajar dan berinteraksi dengan instruktur dan siswa lainnya (Singh dan Thurman, 2019).

Pembelajaran sinkron adalah strategi pembelajaran yang lebih terstruktur, di mana kelasa dijadwalkan pada waktu tertentu dan dalam pengaturan ruang kelas virtual secara langsung. Dengan cara ini, siswa mendapat manfaat dari interaksi waktu nyata, sehingga mendapatkan pesan instan dan umpan balik saat dibutuhkan (Littlefield, 2018). Sedangkan, siswa dalam pembelajaran asinkron tidak bisa mendapatkan umpan balik dan pesan instan. Selain itu, konten pembelajaran tidak tersedia di kelas langsung, melainkan pada sistem atau forum pengelolaan pembelajaran (Learning Management System) yang berbeda (Littlefield, 2018). Beberapa platform sistem pengelolaan pembelajaran yang sering dipergunakan di Indonesia antara lain Google Classroom, Edmodo dan Moodle.

\section{Meningkatkan Efektivitas Pembelajaran Daring}

Salah satu kunci untuk memastikan pendidikan online yang efektif adalah pembelajaran aktif. Pembelajaran aktif mencakup sejumlah mode, metode, dan gerakan pembelajaran terkait. Huang dkk (2020) mengidentifikasi enam dimensi dari pendidikan online yang efektif dalam keadaan darurat. Enam dimensi tersebut, antara lain:

1. Memastikan tersedianya infrastruktur jaringan yang andal

Infrastruktur jaringan yang andal sangat penting untuk mendukung berbagai aktivitas, seperti pengajaran sinkronis menggunakan konferensi video, pembelajaran asinkron dengan mengakses atau mengunduh materi secara digital, dan kolaborasi dengan rekanrekan melalui platform sosial.

2. Memanfaatkan alat pembelajaran yang mudah digunakan

Menggunakan perangkat pembelajaran yang bersahabat bermanfaat bagi peserta didik dalam menemukan dan mengolah informasi, membangun pengetahuan, berkolaborasi dengan teman sebaya, mengungkapkan pemahaman, dan mengevaluasi efek pembelajaran dengan cara yang konkret. Penting juga bagi pengajar untuk menghindari membebani pelajar dan orang tua dengan meminta mereka menggunakan terlalu banyak aplikasi atau platform. Dalam konteks ini, sekolah harus berkoordinasi di antara semua instruktur untuk menggunakan alat atau platform pembelajaran yang konsisten.

3. Mengadopsi sumber belajar digital yang sesuai

Pengajar dituntut untuk mampu menyediakan sumber belajar digital interaktif yang sesuai, seperti kuliah mikro video online, e-book, simulasi, animasi, kuis, dan permainan. Selain itu, pemilihan sumber belajar digital juga harus mencakup beberapa kriteria, yaitu 


\section{Rizky Nastiti, Nurul Hayati}

perizinan, akurasi, interaktivitas, kemudahan adaptasi, relevansi dan sensitivitas budaya, serta kesesuaian konten, kesulitan, struktur, media, dan organisasi.

4. Memfasilitasi pengajaran dan pembelajaran daring yang efektif

Tidak seperti pembelajaran di kelas tradisional, instruksi daring dicirikan dengan memiliki lokasi guru dan pelajar yang berbeda, oleh karena itu pembelajaran yang fleksibel harus mempertimbangkan pengajaran daring yang efektif dan instruksi pembelajaran menggunakan teknologi yang berbeda. Pengajar dapat menggunakan metode yang efektif untuk mengatur instruksi dengan mengadopsi berbagai strategi pengajaran, seperti studi kasus, debat dan diskusi terbuka, dan pembelajaran berdasarkan pengalaman.

5. Memberikan dukungan dan layanan bagi pengajar dan peserta didik

Layanan dukungan yang efektif adalah kunci untuk memastikan kualitas pendidikan online. Layanan dukungan pendidikan online mencakup dua jenis: layanan dukungan untuk pengajaran daring bagi pengajar dan layanan dukungan untuk pembelajaran daring bagi peserta didik. Kedua layanan tersebut dapat diberikan bekerja sama dengan pemerintah, sekolah, perusahaan, keluarga, masyarakat, dan pihak terkait lainnya.

6. Memberdayakan kolaborasi antara pemerintah, perusahaan, dan lembaga pendidikan

Dalam menghadapi kebutuhan pendidikan online selama epidemi dan perkembangannya di masa depan, pemerintah harus memainkan banyak peran dalam panduan kebijakan, koordinasi secara keseluruhan, dan pengawasan yang efektif. Pemerintah juga harus mengoordinasikan perusahaan, sekolah, kampus, lembaga penelitian, keluarga, masyarakat, dan pihak-pihak lainnya untuk membangun platform komunikasi yang lancar, memilih sumber belajar yang sesuai, menyediakan alat pembelajaran yang nyaman, mendorong metode pembelajaran yang beragam dan mendukung metode pengajaran yang fleksibel. Layanan dukungan yang efektif untuk pendidikan online dapat diwujudkan melalui kerja sama yang erat dari berbagai pihak.

\section{Metode Penelitian}

Penelitian ini merupakan descriptive study dimana fokus utamanya adalah mendeskripsikan karakteristik populasi atau fenomena yang diteliti. Teknik pengumpulan data yang digunakan dalam penelitian ini adalah kuesioner dan wawancara. Pengumpulan data dilakukan melalui dua tahap. Tahap pertama dilakukan dari bulan oktober 2020, dimana kuesioner yang diperuntukan bagi mahasiswa disebar secara online dengan menggunakan Google Form dan dengan menyebarkan lembar kuesioner. Selama satu bulan pengumpulan data berlangsung, didapatkan 124 orang responden dari berbagai perguruan tinggi di Kota Banjarmasin. Selanjutnya, pada tahap kedua pengumpulan data berupa kuesioner dibagikan kepada enam orang dosen. Setelah mengolah data dari kuesioner, penelitian kemudian melakukan wawancara secara informal kepada keenam dosen tersebut dengan tujuan memperoleh informasi yang lebih mendetail mengenai permasalahan yang diteliti.

Setelah data dari hasil kuesioner dan wawancara dikumpulkan, data kemudian diolah dan dianalisa. Data yang telah diolah kemudian disajikan dalam bentuk teks, naratif, grafik, tabel, dan bagan yang bertujuan mempertajam pemahaman penelitian terhadap informasi yang dipilih setelah itu disajikan dengan tabel ataupun dengan uraian penjelasan. Pada tahap terakhir, peneliti melakukan penarikan kesimpulan berdasarkan persentasenya. 


\section{Pembahasan}

Pembahasan dari hasil penelitian ini dibagi menjadi dua bagian utama, yaitu deskripsi karakteristik responden dan deskripi hasil penelitian.

\section{Deskripsi Karakterisitik Responden}

Responden dari penelitian ini terdiri atas dua group responden, yaitu responden mahasiswa sebanyak 142 orang dan responden dosen sebanyak enam orang. Berdasarkan karakteristik gendernya, sebagian besar responden berjenis kelamin wanita, yaitu sebanyak 87 orang $(61.27 \%)$ responden. Sedangkan sisanya merupakan responden berjenis kelamin pria, yaitu sebanyak 55 orang (38.73\%) responden.

Sedangkan berdasarkan karateristik Program Studi responden berasal dari beberapa Program Studi. Responden terbanyak berasal dari Program Studi Manajemen, yaitu sebanyak 56 orang ( 39.44\%) responden, disusul dengan responden dari Program Studi Akuntansi sebanyak 35 orang (24.65\%), dan Program Studi Pendidikan Bahasa Inggris sebanyak 26 orang (18.31\%) responden. Respoden lainnya berasal dari Program Studi Teknik Informatika sebanyak 10 orang (7.04\%) responden, Pendidikan Guru Sekolah Dasar sebanyak 4 orang (2.82\%) responden, Ekonomi Syariah sebanyak 2 orang (1.41\%) responden dan Kesehatan Masyarakat sebanyak 2 orang $(1.41 \%)$ responden. Kemudian, masing-masing 1 orang (0.70\%) responden yang berasal dari Program Studi Rekam Medis \& Informasi Kesehatan, Analis Kesehatan, Ilmu Hukum, Manajemen Sumber Daya Perairan, Pendidikan Bahasa dan Sastra Indonesia, Pendidikan Agama Islam dan Ilmu Perpustakaan \& Informasi Islam.

Lebih lanjut, responden juga dikarakteristikan berdasarkan tahun kuliah. Sebanyak 60 orang $(42.25 \%)$ responden merupakan mahasiswa tahun pertama. Kemudian terdapat sebanyak 33 orang (23.24\%) responden merupakan mahasiswa tahun kedua, 23 orang (16.19\%) responden merupakan mahasiswa tahun ketiga, 15 orang (10.56\%) responden merupakan mahasiswa tahun keempat dan 11 orang $(7.75 \%)$ responden merupakan mahasiswa tahun kelima. Hasil ini mengindikasikan sebagian besar responden merupakan mahasiswa yang baru berkuliah satu sampai dua bulan dan masih dalam masa adaptasi dunia perkuliahan.

Karakteristik responden berikutnya adalah berdasarkan usia responden Berdasarkan usianya, responden dibagi menjadi tiga, yaitu sebanyak 79 orang (55.63\%) responden berusian di bawah 20 tahun, 62 orang (43.66\%) responden berusia 20 - 24 tahun, dan 1 orang $(0,71 \%)$ responden berusia $25-30$ tahun.

Sedangkan karakteristik dari responden dosen adalah enam orang dosen dari tiga program studi yang berbeda, yaitu dua orang dosen dari Program Studi Akuntansi, dua orang dosen dari Program Studi Manajemen dan dua orang dosen dari Program Studi Pendidikan Bahasa Inggris. Masing-masing dosen telah memiliki pengalaman mengajar lebih dari tiga tahun.

\section{Deskripsi Hasil Penelitian}

Kuesioner yang diisi oleh responden mahasiswa terdiri atas lima topik utama, yaitu 1) platform yang dipergunakan saat perkuliahan daring; 2) kesiapan mahasiswa menghadapi perkuliahan daring; 3) persepsi mahasiswa terhadap pelaksanaan perkuliahan daring; 4) tantangan yang dialami mahasiswa selama pelaksanaan perkuliahan daring; dan 5) aspek positif yang dirasakan mahasiswa selama pelaksanaan perkuliahan daring. Kuesioner disusun 


\section{Rizky Nastiti, Nurul Hayati}

dengan mengadaptasi kuesioner penelitian A. Patricia (2020), Adnan dan Anwar (2020), Aristovnik dkk (2020) serta Mohalik dan Sahoo (2020).

1) Platform Perkuliahan Daring

Pada topik ini responden diminta untuk memilih platform perkuliahan daring yang mereka pergunaan saat perkuliahan daring dan metode yang seperti apa yang mereka lebih pilih untuk perkuliahan daring.

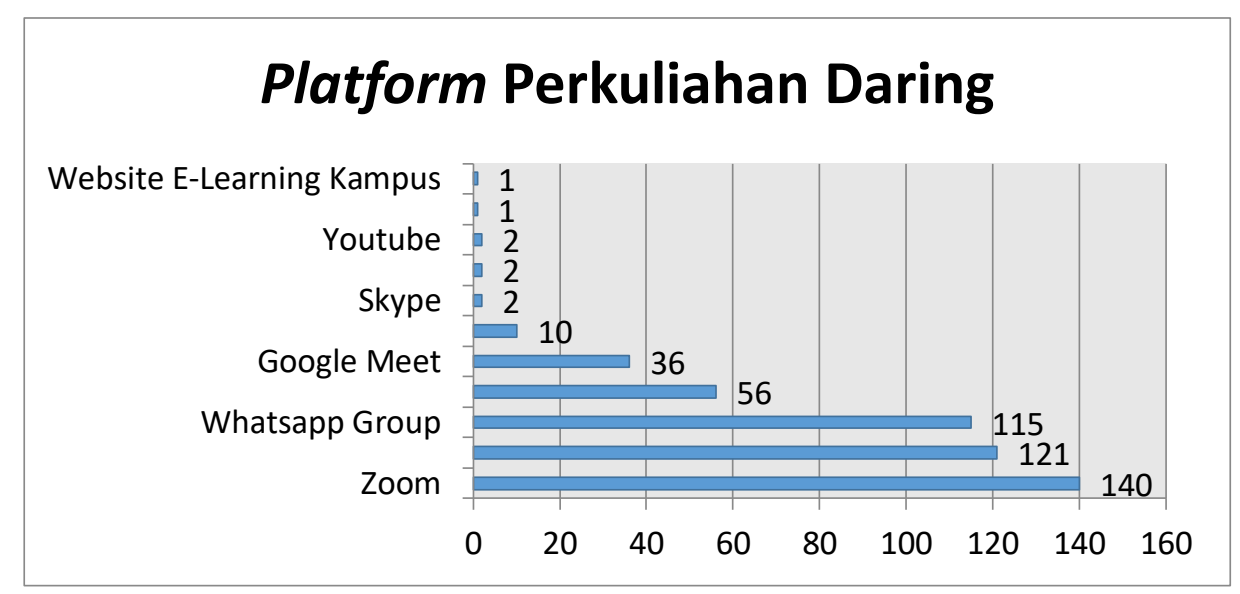

Grafik 1. Platform Perkuliahan Daring yang Sering Dipergunakan

Sumber: data primer diolah, 2020

Berdasarkan Grafik 1, dapat dilihat bahwa sebagian besar responden menggunakan video conference saat perkuliahan, seperti Zoom, Cloudx dan Google Meet sedangkan platform berdasarkan pada Learning Managemen System seperti Google Classroom, Edmodo dan E-Learning website berada di posisi kedua. Selain itu, WhatsApp Group juga banyak dipakai sebagai sarana komunikasi dan pembelajaran satu arah, seperti untuk pemberian materi dan tugas.

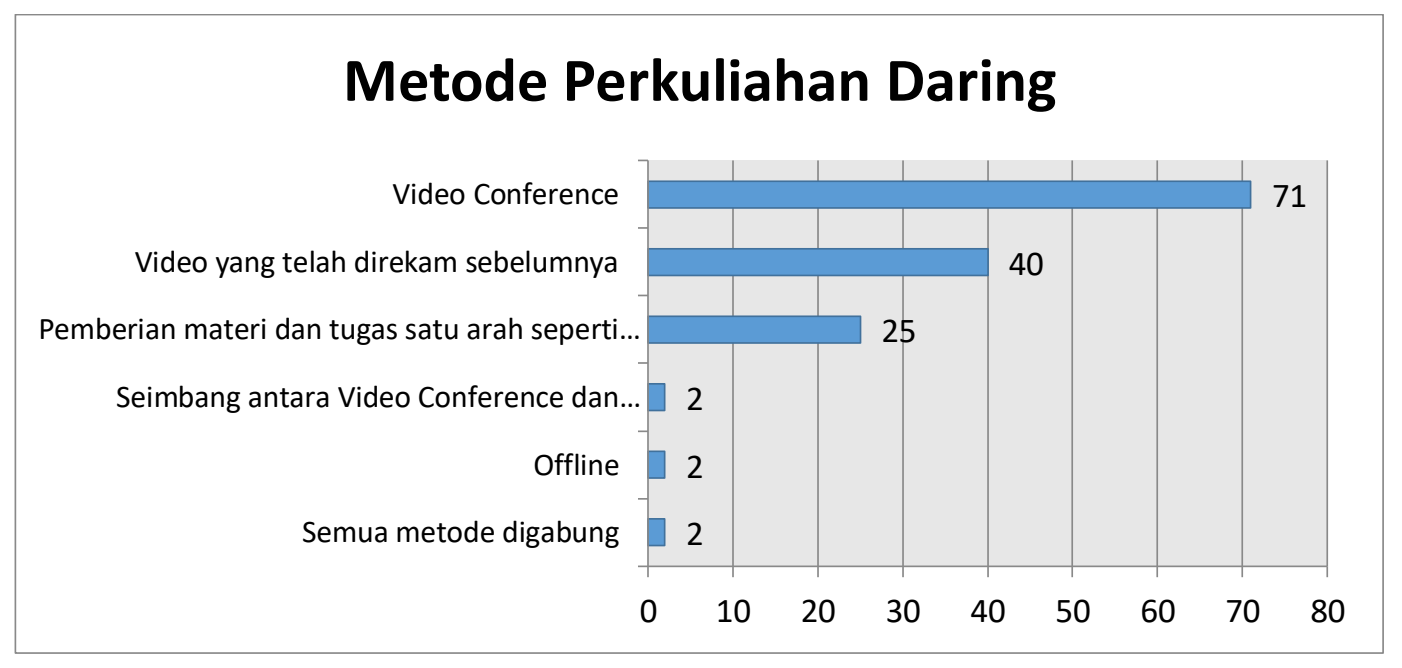

Grafik 2. Metode Perkuliahan Daring yang Dipilih

Sumber: data primer diolah, 2020 


\section{Rizky Nastiti, Nurul Hayati}

Hasil dari Grafik 1 juga didukung oleh hasil dari Grafik 2 yang menyatakan bahwa sebagian besar responden lebih memilih perkuliahan melalui video conference. Sedangkan, 40 orang responden lebih menyukai perkuliah dengan metode menonton video yang telah direkam sebelumnya karena mempermudah mereka untuk memutar ulang video dan menghemat kuota mereka. Sisanya, sebanyak 25 orang responden lebih memilih pemberian materi dan tugas satu arah melalui WhatsApp Group, karena lebih mudah diakses. Beberapa responden juga berbendapat bahwa mereka lebih menyukai jika metode yang digunakan bervariasi, sehingga tidak monoton.

2) Kesiapan Menghadapi Perkuliahan Daring

Tabel 1. Kesiapan Menghadapi Perkuliahan Daring

\begin{tabular}{|c|l|c|c|c|c|}
\hline \multirow{2}{*}{ No } & \multicolumn{1}{|c|}{ Pertanyaan } & \multicolumn{4}{c|}{ Tanggapan } \\
\cline { 3 - 6 } & & \multicolumn{3}{c|}{ IYA } & \multicolumn{3}{c|}{ TIDAK } \\
\cline { 3 - 6 } & & Jumlah & Jumlah & \% \\
\hline 1 & Memiliki Jaringan internet yang baik & 101 & 71.13 & 41 & 28.87 \\
\hline 2 & $\begin{array}{l}\text { Memiliki perangkat / gawai digital yang } \\
\text { mendukung }\end{array}$ & 106 & 74.65 & 36 & 25.35 \\
\hline 3 & Terbiasa dengan perangkat & 108 & 76.06 & 34 & 23.94 \\
\hline 4 & $\begin{array}{l}\text { Memiliki pengetahuan tentang } \\
\text { penggunaan perangkat digital yang baik }\end{array}$ & 107 & 75.35 & 35 & 24.65 \\
\hline 5 & $\begin{array}{l}\text { Memiliki kemampuan menggunakan } \\
\text { perangkat digital yang baik }\end{array}$ & 106 & 74.65 & 36 & 25.35 \\
\hline 6 & Memiliki ruang untuk belajar di rumah & 97 & 68.31 & 45 & 31.69 \\
\hline
\end{tabular}

Sumber: data primer diolah, 2020

Berdasarkan Tabel 1 didapatkan hasil berupa kesiapan mahasiswa dalam menghadapi perkuliahan secara daring. Dari data yang ditampilkan pada Tabel 1 dapat disimpulkan bahwa sebagian besar responden memiliki kesiapan yang baik dalam menghadapi perkuliahan secara daring. Hal ini dapat dilihat dari jawaban responden yang sebagian besar menyatakan bahwa mereka memiliki jaringan internet yang baik dan memiliki perangkat / gawai digital yang mendukung. Selain itu, dari segi kemampuan untuk mempergunakan perangkat digital, responden dianggap memiliki kemampuan yang mencukupi. Hal ini dapat dilihat dari jawaban sebagian besar responden yang menyatakan bahwa mereka terbiasa dengan perangkat, memiliki pengetahuan tentang penggunaan perangkat digital yang baik serta memiliki kemampuan menggunakan perangkat digital yang baik.

Ana dkk (2020) dan Ali (2020) mengungkapkan bahwa persiapan yang baik terutama kesiapan dalam penggunaan perangkat pendukung sangat diperlukan dalam mengimplementasikan pembelajaran daring sehingga aktivitas perkuliahan dapat berjalan dengan efektif. Lebih lanjut, Ali (2020) menyimpulkan bahwa kesiapan sumber daya, kesiapan staf, kepercayaan diri, aksesibilitas dan motivasi siswa memainkan fungsi penting dalam mewujudkan pembelajaran berbasis teknologi informasi dan informasi yang terintegrasi.

Berdasarkan hasil yang disajikan, dapat disimpulkan bahwa mahasiswa memiliki kesiapan yang baik dalam menghadapi perkuliahan secara daring karena mahasiswa memiliki perangkat yang mendukung. Selain itu, mereka juga memiliki kemampuan yang mencukupi untuk menggunakan perangkat tersebut selama perkuliahan secara daring. 
INOBIS: Jurnal Inovasi Bisnis dan Manajemen Indonesia

Volume.03, Nomor.03, Juni 2020

\section{Rizky Nastiti, Nurul Hayati}

3) Persepsi terhadap Pelaksanaan Perkuliahan Daring

Tabel 2. Persepsi terhadap Pelaksanaan Perkuliahan Daring

\begin{tabular}{|l|l|c|c|c|c|}
\hline \multirow{2}{*}{ No Pertanyaan } & \multicolumn{4}{|c|}{ Tanggapan } \\
\cline { 3 - 6 } & & \multicolumn{2}{|c|}{ IYA } & \multicolumn{2}{c|}{ TIDAK } \\
\cline { 3 - 6 } & & Jumlah & \% & Jumlah & $\%$ \\
\hline 1 & $\begin{array}{l}\text { Kuliah secara daring adalah solusi yang } \\
\text { baik saat PSBB }\end{array}$ & 131 & 92.25 & 11 & 7.75 \\
\hline 2 & $\begin{array}{l}\text { Kuliah secara daring meningkatkan } \\
\text { kemampuan belajar secara mandiri }\end{array}$ & 98 & 69.01 & 44 & 30.99 \\
\hline 3 & $\begin{array}{l}\text { Belajar secara daring lebih baik dari } \\
\text { pada belajar tatap muka }\end{array}$ & 15 & 10.56 & 127 & 89.44 \\
\hline 4 & $\begin{array}{l}\text { Mengalami kesulitan saat kuliah secara } \\
\text { daring }\end{array}$ & 125 & 88.03 & 17 & 11.97 \\
\hline 5 & $\begin{array}{l}\text { Dosen atau pengajar juga mengalami } \\
\text { kesulitan saat kuliah secara daring }\end{array}$ & 115 & 80.99 & 27 & 19.01 \\
\hline 6 & $\begin{array}{l}\text { Merasa terisolasi saat kuliah secara } \\
\text { daring }\end{array}$ & 88 & 61.97 & 54 & 38.03 \\
\hline 7 & Merasa stress saat kuliah secara daring & 84 & 59.15 & 58 & 40.85 \\
\hline 8 & $\begin{array}{l}\text { Perkulihaan tatap muka dengan dosen } \\
\text { penting bagi pembelajaran }\end{array}$ & 131 & 92.25 & 11 & 7.75 \\
\hline 9 & $\begin{array}{l}\text { Tugas atau proyek kelompok lebih } \\
\text { mudah dikerjakan secara daring }\end{array}$ & 43 & 30.28 & 99 & 69.72 \\
\hline
\end{tabular}

Sumber: data primer diolah, 2020

Berdasarkan data yang disajikan pada Tabel 2, dapat dilihat bahwa hampir semua responden beranggapan bahwa kuliah secara daring merupakan solusi yang baik di masa pandemi saat ini. Hasil ini sejalan dengan pendapat Zhang dkk (2020) yang mengungkapkan bahwa sistem pembelajaran daring dijalankan sebagai sebuah solusi menangguhkan perkuliahan tatap muka tanpa menghentikan perkuliahan.

Lebih lanjut lagi, responden beranggapan bahwa kuliah secara daring dapat meningkatkan kemampuan belajar secara mandiri mereka. Meskipun demikian, hampir semua responden lebih memilih kuliah secara tatap muka dibandingkan kuliah secara daring. Hal ini disebabkan karena mereka mengalami kendala-kendalan saat menjalani perkuliahan secara daring. Sebagian besar dari responden merasa terisolasi dan merasa stres saat berkuliah secara daring. Mohalik dan Sahoo (2020) dalam penelitiannya menyimpulkan bahwa salah satu penyebab mahasiswa mengalami stres saat perkuliahan secara daring adalah mereka merasa terisolasi karena kurangnya interaksi secara langsung.

Responden juga merasa kesulitan mengerjakan tugas atau proyek kelompok secara daring karena kesulitan dalam berkomunikasi dengan teman satu kelompok. Selain itu, mereka juga beranggapan dosen juga mengalami kesulitan saat perkuliahan secara daring. Sehingga, berdasarkan hasil persepsi mahasiswa dapat disimpulkan bahwa mahasiswa lebih memilih perkuliahan secara tatap muka dibandingkan perkuliahan secara daring karena beberapa kendala yang mereka alami selama berkuliah secara daring. 


\section{Rizky Nastiti, Nurul Hayati}

4) Tantangan Selama Pelaksanaan Perkuliahan Daring

Tantangan yang dialami responden selama perlaksanaan perkuliah daring dibagi menjadi tiga poin utama, yaitu 1) tantangan situasional dan lingkungan, 2) tantangan pendidikan online, dan 3) tantangan emosional (A. Particia, 2020)

Tabel 3. Tantangan Selama Pelaksanaan Perkuliahan Daring

\begin{tabular}{|c|c|c|c|c|c|}
\hline \multirow{3}{*}{ Tantangan } & \multirow{3}{*}{ Pertanyaan } & \multicolumn{4}{|c|}{ Tanggapan } \\
\hline & & \multicolumn{2}{|c|}{ MENGALAMI } & \multicolumn{2}{|c|}{$\begin{array}{c}\text { TIDAK } \\
\text { MENGALAMI }\end{array}$} \\
\hline & & Jumlah & $\%$ & Jumlah & $\%$ \\
\hline \multirow{5}{*}{$\begin{array}{l}\text { Situasional } \\
\& \\
\text { Lingkungan }\end{array}$} & Sulit berkonsentrasi saat di rumah & 99 & 69.72 & 43 & 30.28 \\
\hline & Stres menyeimbangkan kehidupan & 81 & 57.04 & 61 & 40.96 \\
\hline & Kesulitan finansial & 62 & 43.66 & 80 & 56.34 \\
\hline & Kurangnya interaksi sosial & 82 & 57.75 & 60 & 42.25 \\
\hline & Perubahan hidup mendadak & 100 & 70.42 & 42 & 29.57 \\
\hline \multirow{4}{*}{$\begin{array}{l}\text { Pendidikan } \\
\text { Online }\end{array}$} & Kuliah secara daring itu sulit & 101 & 71.13 & 41 & 28.87 \\
\hline & $\begin{array}{l}\text { Tugas- tugas kuliah menjadi } \\
\text { bertambah }\end{array}$ & 103 & 72.54 & 39 & 27.47 \\
\hline & $\begin{array}{l}\text { Tidak konsentrasi saat kuliah } \\
\text { daring }\end{array}$ & 105 & 73.94 & 37 & 26.06 \\
\hline & $\begin{array}{l}\text { Tidak terbiasa dengan teknologi } \\
\text { daring }\end{array}$ & 56 & 39.44 & 86 & 60.56 \\
\hline \multirow{2}{*}{ Emosional } & Kurangnya motivasi & 73 & 51.41 & 64 & 45.07 \\
\hline & Perasaan- perasaan negatif & 57 & 40.14 & 85 & 40.14 \\
\hline
\end{tabular}

Sumber: data primer diolah, 2020

Tabel 3 menyajikan data mengenai tantangan yang dihadapi mahasiswa selama pelaksanaan perkuliahan daring. Pada data di Tabel 3 dapat dilihat bahwa tantangan situasional dan lingkungan yang dialami oleh responden adalah sulit berkonsentrasi saat di rumah, stress menyeimbangkan kehidupan, kurangnya interaksi sosial dan perubahan hidup yang mendadak dikarenakan COVID-19. Lebih lanjut lagi, mereka juga merasa perkuliahan secara daring sulit bagi mereka. Mereka merasa tidak dapat berkonsentrasi dengan baik saat berkuliah secara daring. Menurut A. Patricia (2020), salah satu penyebab mahasiswa sulit berkonsentrasi saat perkuliahan secara daring adalah situasi rumah mereka yang kurang mendukung, seperti situasi rumah yang bising dan persepsi mereka terhadap rumah sebagai tempat beristirahat.

Selain itu, responden juga beranggapan bahwa selama berkuliah secara daring tugastugas kuliah menjadi bertambah. Aristovnik dkk (2020) mengungkapkan bahwa kemampuan yang kurang memadai dalam menggunakan komputer dan persepsi bahwa selama perkuliahan secara daring tugas-tugas mereka menjadi bertambah menyebabkan mahasiswa terkendalan untuk mencapai hasil yang lebih baik selama beradaptasi dengan pembelajaran jarak jauh ini. Beberapa responden juga menyatakan motivasi mereka berkurang selama pandemi ini. Adnan dan Anwar (2020) dalam penelitiannya mengungkapkan bahwa sebagian besar mahasiswa lebih termotivasi saat pembelajaran konvensional dibandingkan pembelajaran jarak jauh. Meskipun mereka dapat mengatur waktu belajar mereka secara efektif secara daring, namum mereka beranggapan bahwa perkuliahan yang lengkap tidak dapat dipenuhi sepenuhnya secara daring. 


\section{Rizky Nastiti, Nurul Hayati}

Berdasarkan hasil tersebut maka dapat disimpulkan bahwa pandemi ini membawa perubahan hidup yang mendadak sehingga merasa sulit berkonsentrasi, merasa stress, dan merasa terbatasnya interaksi sosial. Selain itu, mahasiswa juga merasa kesulitan berkonsentrasi saat berkuliah secara daring dan merasa terbebani dengan tugas-tugas kuliah.

Pada pertanyaan terbuka di kuesioner mengenai tantangan selama berkuliah secara daring, responden juga mengemukakan beberapa kendala lainnya. Mereka mengungkapkan bahwa mereka lebih sulit memahami materi yang diberikan selama perkuliahan secara daring jika dibandingkan saat berkuliah secara tatap muka. Selain itu, dari jawaban responden dapat disimpulkan bahwa kendala utama responden adalah jaringan internet yang tidak stabil dan penggunaan kuota internet yang boros. Seperti yang diungkapkan oleh Giatman dkk (2020) dan Wijaya dkk (2020), jaringan internet yang kurang mendukung merupakan kendala utama mahasiswa selama mengikuti perkuliahan secara daring. Lebih lanjut lagi, Huang dkk (2020) menyatakan bahwa infrastruktur jaringan yang andal sangat penting untuk mendukung berbagai aktivitas, seperti pengajaran sinkronis menggunakan konferensi video, pembelajaran asinkron dengan mengakses atau mengunduh materi secara digital, dan kolaborasi dengan rekan-rekan melalui platform sosial. Oleh karena itu, dukungan pemerintah dalam menyediakan insfrastruktur jaringan yang andal sangat diperlukan agar perkuliahan secara daring di masa pandemi dapat berlangsung dengan lancar.

5) Aspek Positif Pelaksanaan Perkuliahan Daring

Tabel 4. Hasil Tanggapan Aspek Positif Pelaksanaan Perkuliahan Daring

\begin{tabular}{|l|l|c|c|c|c|}
\hline \multirow{2}{*}{ No } & \multirow{2}{*}{ Pertanyaan } & \multicolumn{4}{|c|}{ Tanggapan } \\
\cline { 3 - 6 } & & \multicolumn{3}{c|}{ IYA } & \multicolumn{2}{c|}{ TIDAK } \\
\cline { 3 - 6 } & & Jumlah & \% & Jumlah & \% \\
\hline 1 & Lebih banyak waktu untuk keluarga & 129 & 90.85 & 13 & 9.15 \\
\hline 2 & Lebih baik dalam mengatur waktu & 102 & 71.83 & 40 & 28.17 \\
\hline 3 & Waktu istirahat lebih banyak & 110 & 77.46 & 32 & 22.54 \\
\hline 4 & Meluangkan waktu untuk hobby & 107 & 73.35 & 35 & 24.65 \\
\hline 5 & Mendapatkan skill baru & 87 & 61.27 & 55 & 38.73 \\
\hline 6 & $\begin{array}{l}\text { Tidak ada aspek atau perubahan yang } \\
\text { positif }\end{array}$ & 39 & 27.46 & 103 & 27.46 \\
\hline
\end{tabular}

Sumber: data primer diolah, 2020

Berdasarkan data yang disajikan pada Tabel 4, dapat dilihat bahwa sebagian besar responden merasakan aspek positif dari perkuliahan secara daring. Mereka beranggapan lebih banyak waktu luang yang mereka miliki selama perkuliahan secara daring berlangsung, sehingga mereka memiliki waktu yang lebih banyak untuk keluarga, untuk beristirahat dan untuk melakukan hobby mereka. Selain itu mereka juga beranggapan bahwa selama perkuliahan secara daring mereka lebih baik dalam mengatur waktu. Hasil ini sejalan dengan pernyataan A. Patricia (2020) dalam penelitiannya mengungkapkan bahwa selama pandemi ini mahasiswa menyatakan bahwa mereka memiliki waktu luang yang lebih banyak untuk keluarga dan aktifitas baru, seperti menulis puisi, berolahraga, memperlajari bahasa baru maupun melakukan hobby mereka.

Pada pertanyaan terbuka di kuesioner mengenai aspek positif yang dialami selama berkuliah secara daring, responden juga mengemukakan beberapa aspek positif lainnya. Salah satunya adalah meningkatkan kemampuan belajar secara mandiri. Menurut Firman (2020) perkuliahan secara daring dapat meningkatkan kemandirian belajar mahasiswa karena jika 


\section{Rizky Nastiti, Nurul Hayati}

mereka tidak bisa mengatur waktu dengan baik mereka akan mengalami kesulitan mengikuti jadwal perkuliahan secara daring yang dapat berubah sewaktu-waktu dan mengumpulkan tugas-tugas kuliah yang sudah diberi tenggat waktu. Beberapa mahasiswa juga mengungkapkan bahwa mereka dapat mengurangi biaya transportasi mereka ke kampus karena perkuliahan dilakukan secara daring. Dengan demikian, dapat disimpulkan bahwa meskipun mahasiswa mengalami berbagai kendalan selama mengikuti perkuliahan secara daring, mereka juga merasakan dampak positifnya, salah satunya adalah memiliki lebih banyak waktu luang.

\section{6) Kesiapan dan Tatangan Dosen Selama Perkuliahan Secara Daring}

Berdasarkan data dari hasil kuesioner dan wawancara didapatkan bahwa keenam dosen memiliki jaringan internet yang baik dan memiliki perangkat atau gawai digital yang mendukung. Selain itu, lima orang dosen mengumgkapkan bahwa mereka terbiasa dengan perangkat atau gawai digital dan memiliki kemampuan menggunakan perangkat digital dengan baik. Satu orang dosen menyatakan bahwa responden mengalami kesulitan dalam menggunakan perangkat digital karena tidak terbiasa menggunakannya dan faktor usia. Selanjutnya, hanya satu orang dosen memiliki pengetahuan tentang penggunaan aplikasi belajar secara daring. Hal ini dikarenakan kelima dosen yang lain tidak pernah menggunakan aplikasi belajar daring sebelumnya. Sehingga dapat disimpulkan bahwa secara umum, dosen memiliki kesiapan dalam melaksanakan perkuliahan secara daring dan sebelum perkuliahan secara daring dilaksanakan mereka mendapatkan pelatihan mengenai penggunaan aplikasi belajar daring.

Meskipun keenam dosen tersebut memiliki kesiapan yang baik, mereka tentu saja juga mengalami beberapa kendala selama melaksanakan perkuliahan secara daring. Salah satu kendala yang mereka alami adalah kurangnya interaksi dengan mahasiswa. Hal ini disebabkan karena mahasiswa yang pasif saat perkuliahan berlangsung. Komunikasi dan interaksi yang tidak berjalan dengan lancar antara dosen dan mahasiswa juga mengakibatkan materi kuliah kurang dapat diterima dengan baik oleh mahasiswa sehingga perkuliahan berlangsung kurang efektif dan tujuan perkuliahan belum dapat tercapai. Menurut Adnan dan Anwar (2020), kurangnya interaksi tatap muka dengan dosen dan tidak adanya sosialisasi secara langsung adalah beberapa masalah yang disoroti selama perkuliahan daring pada perguruan tinggi. Selain itu, hasil penelitian ini sejalan dengan hasil penelitian yang dilakukan oleh Wijaya dkk (2020) yang menyimpulkan bahwa pada masa pandemi seperti ini, mahasiswa dan dosen kurang maksimal dalam berkomunikasi dan bersosialisasi secara daring, seperti diskusi yang kurang efektif saat perkuliahan secara daring.

Kendala lainnya adalah jaringan yang terkadang mengalami gangguan serta beberapa mahasiswa yang tidak komitmen saat perkuliah, sebagai contoh memasuki perkuliahan melebihi batas waktu yang ditentukan dan mengikuti kuliah sambil mengerjakan kagiatan yang lain. Beberapa dosen juga mengemukakan aspek positif dari penyelenggaraan perkuliahan secara daring, yaitu memanfaatkan metode baru yang belum pernah dipergunakan saat perkuliahan tatap muka, seperti menggunakan video conference. Hal yang sama juga didapatkan dari hasil penelitian Wijaya dkk (2020) yang mengungkapkan bahwa selama perkuliahan di masa pandemi ini dosen dituntut untuk memperbaharui bahan ajar mereka agar dapat digunakan selama perkuliahan secara daring.

Dari hasil wawancara, mereka juga mengungkapkan alasan mereka menggunakan metode mengajar tertentu. Beberapa orang dosen yang lebih sering menggunakan video conference mengemukakan bahwa dengan menggunakan platform seperti Zoom, CloudX maupun Google Meet mereka dapat berinteraksi lebih baik dengan mahasiswa. Dosen lain yang menggunakan video rekaman mengungkapkan bahwa penggunaaan video penjelasan 


\section{Rizky Nastiti, Nurul Hayati}

merupakan metode yang lebih efektif karena mahasiswa dapat mengulang video apabila masih belum dapat memahami materi yang diberikan kemudian kesulitan mahasiswa dapat didiskusikan melalui aplikasi chat, seperti WhatsApp Group. Sedangkan, dosen yang lebih sering menggunakan metode pemberian materi dan tugas satu arah melalui WhatsApp Group mengungkapkan bahwa metode ini lebih mudah digunakan dan tidak memerlukan jaringan internet yang kuat. Beberapa dosen juga menambahkan bahwa perkuliahan daring yang ideal adalah dimana jaringan internet yang kuat dan stabil tersedia.

\section{Kesimpulan}

Dalam rangka pemutusan penyebaran COVID-19, kebijakan pembelajaran daring diberlakukan sebagai sebuah solusi pengganti pembelajaran tatap muka di perguruan tinggi. Tentu saja selama pelaksanaannya banyak kendala yang dialami oleh mahasiswa dan dosen. Hasil dari penelitian ini menunjukkan bahwa baik mahasiswa maupun dosen memiliki kesiapan yang baik dalam menghadapi perkuliahan secara daring dikarenakan sebagaian besar telah memiliki dan mampu mempergunakan perangkat digital yang mendukung. Lebih lanjut lagi, dapat disimpulkan bahwa selama mengikuti perkuliahan secara daring, mahasiswa mengalami beberapa kendala antara lain merasa stress dan terbatasnya interaksi sosial. Selain itu, mahasiswa juga merasa kesulitan berkonsentrasi saat berkuliah secara daring dan merasa terbebani dengan tugas-tugas kuliah. Ditambah lagi dengan kendala jaringan internet yang tidak stabil dan penggunaan kuota internet yang boros membuat aktifitas perkuliahan daring mahasiswa menjadi tidak efektif. Meskipun mahasiswa mengalami berbagai kendalan selama mengikuti perkuliahan secara daring, mereka juga merasakan dampak positifnya, salah satunya adalah memiliki lebih banyak waktu luang, sehingga mereka memiliki waktu yang lebih banyak untuk keluarga, untuk beristirahat dan untuk melakukan hobby mereka. Sedangkan kendala utama yang dihadapi oleh dosen adalah kurangnya interaksi dengan mahasiswa sehingga perkuliahan berlangsung kurang efektif.

Demi mendukung berjalannya perkuliahan daring secara efektif, diperlukan kerjasama dari berbagai pihak terutama pihak perguruan tinggi dan pemerintah. Perguruan tinggi dapat menyediakan aplikasi belajar daring yang mudah dipergunakan dan mengadakan pelatihan penggunakan aplikasi belajar daring tersebut agar dapat dipergunakan secara efektif oleh mahasiswa dan dosen. Selain itu, program pemerintah berupa kuota internet pendidikan dari Kementerian Pendidikan dan Kebudayaan masih perlu ditingkatkan agar semua mahasiswa dapat menerima bantuan kuota tersebut. Pemberian kuota internet pendidikan yang lebih merata diharapkan dapat menjangkau semua mahasiswa sehingga dapat membantu mengurangi beban mahasiswa dalam pembelian kuota internet.

Seiring dengan adanya wacana dilaksanakannya hybrid learning, yaitu perkuliahan yang menggabungkan perkuliahan tatap muka dan secara daring oleh Kementerian Pendidikan dan Kebudayaan, persiapan untuk menghadapi implementasi sistem perkuliahan baru tersebut sangat diperlukan. Perguruan Tinggi pun dituntut untuk menyusun dan menerapkan standar operasional prosedur (SOP) protokol kesehatan serta menerbitkan pedoman belajar, wisuda, maupun kegiatan kampus lainnya. Persiapan ini sangat diperlukan dalam rangka mendukung berjalannya kegiatan perkuliahan yang lancar dan mencegah penyebaran Covid-19. Pembahasan ini dapat dijadikan bahan pertimbangan bagi peneliti selanjutnya yang tertarik untuk menilik lebih jauh mengenai kesiapan perguruan tinggi dalam menjalankan perkuliahan tatap muka di masa pandemi. 


\section{Daftar Pustaka}

A. Patricia. (2020). "College Students' Use and Acceptance of Emergency Online Learning Due to COVID-19". International Journal of Educational Research Open.

Adnan, M. \& Anwar, K. (2020). "Online Learning amid the COVID-19 Pandemic: Students' Perspectives." Journal of Pedagogical Sociology \& Psychology, 2(1).

Ali, W. (2020). "Online and Remote Learning in Higher Education Institutes: A Necessity in light of COVID-19 Pandemic". Higher Education Studies, 10(3).

Ana, A., Minghat, A.D., Purnawarman, P., Saripudin, S., Muktiarni, M., Dwiyanti, V., \& Mustakim, S.S. (2020). "Students' Perceptions of the Twists and Turns of E-learning in the Midst of the Covid 19 Outbreak". Revista Romaneasca pentru Educatie Multidimensionala, 12(1Sup2), 15-26.

Aristovnik, A., Keržič, D., Ravšelj, D., Tomaževič, N., \& Umek, L. (2020). "Impacts of the COVID-19 Pandemic on Life of Higher Education Students: A Global Perspective". Sustainability 2020, 12.

Irfan, M., Kusumaningrum, B., Yulia, Y., \& Widodo, S. A. (2020). "Challenges during the pandemic: Use of e-learning in mathematics learning in higher education". Infinity, 9(2), 147-158.

Firman. (2020). "Dampak Covid-19 Terhadap Pembelajaran di Perguruan Tinggi", BIOMA, 2(1), 14-20.

Giatman, M., Siswati, S., \& Basri, I. Y. (2020). "Online Learning Quality Control in the Pandemic Covid-19 Era in Indonesia." Journal of Nonformal Education, 6(2).

Huang, R. H., Liu, D. J., Tlili, A., Yang, J. F., \& Wang, H. (2020). Handbook on Facilitating Flexible Learning during Educational Disruption: The Chinese Experience in Maintaining Undisrupted Learning in COVID-19 Outbreak. Diakses dari https://iite.unesco.org/wp-content/uploads/2020/03/Handbook-on-Facilitating-

Flexible-Learning-in-COVID-19-Outbreak-SLIBNU-V1.2-20200315.pdf pada bulan September 2020.

Mohalik, R., \& Sahoo, S. (2020). "E-Readiness and Perception of Student Teachers Towards Online Learning in the Midst of COVID-19 Pandemic". Diakses dari https://dx.doi.org/10.2139/ssrn.3666914 pada bulan September 2020.

Singh, V., \& Thurman, A. (2019). "How Many Ways Can We Define Online Learning? A Systematic Literature Review of Definitions of Online Learning (1988-2018)". American Journal of Distance Education, 33.4: 289- 306.

Tanveer, M., Bhaumik, A., Hassan, S., \& Ul Haq., I. (2020). "Covid-19 Pandemic, Outbreak Educational Sector and Students Online Learning in Saudi Arabia". Journal of Entrepreneurship Education, 23 (3).

Toquero, C. M. (2020). "Challenges and Opportunities for Higher Education amid the COVID-19 Pandemic: The Philippine Context". Pedagogical Research, 5(4).

Wijaya, R., Lukman, M., \& Yadewani, D. (2020). "Dampak Pandemi COVID-19 Terhadap Pemanfaatan E-Learning" DIMENSI, 9(2).

UNESCO. (2020). COVID-19 Educational Disruption and Response. Diakses dari https://en.unesco.org/covid19/educationresponse/ pada bulan September 2020.

Zhang, W., Wang, Y., Yang, L., \& Wang, C. (2020). "Suspending Classes without Stopping Learning: China's Education Emergency Management Policy in the COVID-19 Outbreak". J. Risk Financial Manag., 13, 55. 